\title{
THE IMPLEMENTATION OF HOTS IN TEACHING ENGLISH PROCESS AT TENTH GRADE OF MTI PASIA
}

\author{
Sesmiyanti ${ }^{1}$ \\ ${ }^{1}$ IAIN Bukittinggi \\ Email : miases75@gmail.com
}

\begin{abstract}
This research was conducted because HOTS is a significant factor in achieving the learning process in accordance with the 2013 curriculum, HOTS is a solution that students become active and participatory in the learning process, teachers not only explain learning in front of the class, but students must be more active to describe the problems that were found during learning, therefore, the researcher wanted to investigate how the HOTS process was implemented in teaching English at X grade of MTI Pasia in the 2019/2020 school year. The purpose of this research to know how the English teacher at X grade of MTI Pasia apply HOTS in Teaching English process, especially in developing productive and receptive skills, according to the level of critical thinking. The type of this research was a qualitative descriptive study. The instruments of this study were documentation (document analysis) and observation sheets to collected the data. The subjects in this study was X grade English teachers at MTI Pasia in the 2019/2020 academic year. The results of this study obtained from the document analysis and observation sheets found that, the English teacher at X grade of MTI Pasia did not apply HOTS in teaching English and learning process. The English teacher only applied HOTS to the learning design, it was not apply to the process in learning, this happened not because it was caused by online learning due to COVID 19 pandemic, but it was happened because the teacher did not encourage learning to be effective during the pandemic, the teacher should still be able to improve the learning process using technological advances, even though it was still a long of perfection than face-to-face learning.
\end{abstract}

\section{Keywords: Implementation, HOTS, Teaching English}

\section{INTRODUCTION}

Education in the 21st century is marked by the development of several characteristics of education that must be useful for students. the first is thedevelopment of learning using a studentcentered. Students as learning subjects who actively develop their interests and potential. Students are not required to listen and memorize the subject matter provided by the teacher, but try to construct their knowledge and skills.

Education should be collaborative. Learners to be able to collaborate with friends in class. In working on a project, students need to be taught how to appreciate each person's strengths and 
talents as well as how to take part and it. The learning process should have in context. Teachers develop learning methods that allow students to connect with the real world. The teacher helps students to find value, meaning and belief in what they are learning and can apply it in their daily lives. The teacher assesses student performance that is associated with the real world. So, these characters should be possessed by students to help them in facing the challenges of the times that demand the student can solve their own problems in learning.

Education in the 21 st century is simply interpreted as transformed learning. It means that, skills that are need to be achieved by students is not only LOTS (Lower Order Thinking Skills), but there must also be an increase to HOTS (Higher Order Thinking Skills). HOTS is a process of thinking in a higher cognitive level that is developed from a variety of cognitive concepts and methods and taxonomies of learning, teaching, and assessment. The main purpose of high order thinking skills is how to improve the ability to think critically in receiving various types of information. So, HOTS can be one way to encourage students to be able to solve their own problems by thinking critically.

Margana \& Widyantoro (2017) state that point out that the use of critical thinking (higher-order thinking skills) is recognized as a main capability to maximally enhance students' academic language. From that notion, the relationship between thinking and language learning particularly in writing, speaking, listening and reading skills are highly significant. Higher-order thinking skills includes some active skills which with those active skills the students can handle their productive task. It is believed that to improve students' productive and receptive skills also need to improve their higher-order thinking.

The purpose of this research to know how the English teacher at X grade of MTI Pasia apply HOTS in Teaching English process, especially in developing productive and receptive skills according to the level of critical thinking. it can be concluded that integrating HOTS into learning is a must, it is intended that HOTS is not just about making questions for assessment. HOTS in learning means the ability to think critically, logically, reflectively and metacognitively. The 2013 curriculum demands that learning materials are designed to encourage students to be able to predict, design, and predict. The teacher-centered learning model is no longer relevant. Students should be the center of learning (student-centered learning). 


\section{METHOD}

The design of this research is qualitative research. Sugiyono (2010) states that qualitative research is the research method that based on post-positivism philosophy which is used to research natural condition where researcher as main instrument. the researcher will apply descriptive qualitative because it can help the researcher to get information from informant based on the research question, and this purpose to know how the implementation of HOTS in teaching English, so the qualitative design is an appropriate research design to be used in this research.

The informant of the research is the English teacher of tenth grade students of MTI Pasia. The researcher used purposive sampling in determining the informant. As Margono (2007) stated, purposive sampling will used if the sample has some certain criteria that relate to the purpose of the study. There is the teacher in teaching English at tenth grades of MTI Pasia, the teacher said that, the teacher used HOTS criteria in teaching English process. Then, researcher choose one teacher as the key of informant of this research. The crucial step in doing a research in collecting the data to collecting the data, the researcher used observation and document analysis, for document analysis the researcher will analyze the lesson plan that made by the teacher based on HOTS criteria. After the data collected, the researcher analyses the data from documentation and observation to achieve the intended purposes. As Sugiyono (2010) the procedures are: data reduction, data display, Conclusion drawing or verification, Triangulation of the data

\section{FINDINGS AND DISCUSSION}

\section{A. FINDING}

This chapter reveals the finding of the data collected through document analysis and observation to answer the research question, that is how does the English teacher at tenth grade of MTI Pasia apply HOTS in teaching productive skills? and how does the English teacher at tenth grade of MTI Pasia apply HOTS in teaching receptive skills?

The data of this research focused on HOTS activities that the teacher applied to the learning process. This research used document analysis to analyze the teacher's lesson plan based on HOTS criteria. The researcher analyzed 4 lesson plans that were used to find out how the HOTS criteria was implemented in the lesson plan. This research also used observation conducted in 5 meetings, observation used to know how HOTS was implemented in learning English process. 
The data in the document analysis aims to seen how the teacher implemented HOTS criteria in planning the lesson, in 4 basic competencies, the researcher also wanted to know how the learning process wasplaned for productive and receptive skills.

The observation aims to seen the activities of the teacher in teaching English. The teacher used online learning process because of the Covid-19 pandemic. The researcher joined the WA group and also Google classroom that used by the teacher, at the first meeting this observation was on 17th September, and the second meeting continued on September 23rd, for the third meeting on September 24th, the fourth meeting on September 30th, and the fifth meeting on October 8th. Based on the result of the document analysis and observation, the researcher presents the finding of the study below.

\section{The implementation of HOTS in teaching productive skill}

\section{a. Lesson plan}

This section presents the findings of the research by conducting documents analysis (Teacher's lesson plan). This is related to how the teachers planed the lesson based on HOTS criteria. Finally, the researchers got some data. The research findings are presented below.

The first part of the lesson plan is related to the identity of the course. There is information in course identity, such as the identity of the school, core competencies (KI), basic competencies (KD), there are cumulative grade point average (IPK), learning objectives, and also learning models (discovery learning, problem-based learning, project-based learning). The results found by the researcher, the teacher complemented the identity of the course in 4 lesson plans. The learning model that the teacher used in 4 lesson plans were discovery learning, Problem Based Learning (PBL) and the teacher also used the question and answer learning method, interviews, discussions, and role-playing. So, in this first part, what the teacher created was complete.

The second part there is a formulation of preliminary activities, this activity aims to initiate learning that contains orientation, such as opening and praying, checking student attendance. Then apperception, this is useful for connecting past lessons with what will be taught at present. The motivation contains the benefits of learning in everyday life. The researcher found that in the 4 lesson plans, the teacher complemented introductory activities properly. So, what the teacher described in the process of orientation, apperception, and motivation in the lesson plan was complete. 
The third part is core activities, in this activities, there are scientific approach (observing, questioning, exploration, association, communication), and also in core activities, there are 4c (creativity, critical thinking, communication, collaboration), there are a thinking process and skills (PPK) which contain remembering, understanding, applying, analyzing, evaluating, creating, and the last there are techniques for developing learning and techniques for assessing students 'writing and speaking skills.

The researcher found that, the teacher developed the core activities completely on each lesson plan. There were materials to increase productive skill such as the teacher gave expressions in 3 lesson plans (talking about self, congratulating and compliment, expressing intention) for speaking activities, then the teacher asked students to communicate orally, and present material with confidence from the different ways of each context, this activity contained in the collaboration process. The teacher prepared reference material only from textbooks and student worksheets for speaking and writing process. For the writing process, students asked to make conclusions about how the form of the expression that the students learned, this study was also found in 5 meetings for 4 lesson plans.

The fourth part is a closing activity that contains feedback on the learning process. The teacher must inform the plan of learning activities for the next meeting, and there is also assessment (attitude assessment, knowledge assessment, skills assessment), in this section, the researcher found that in 4 lesson plans the teacher made a complete closing activity.

The final results of what the researcher found that, the teacher understood the form of lesson plans based on the HOTS criteria, and how productive skills were described in the lesson plan. From the document analysis, the researcher found that the lesson plans made by the teacher accordance with the HOTS criteria, applied by the Ministry of Education and Culture of Indonesia. Thus, the teacher's understanding of making lesson plans was correct, and the teacher has implemented the HOTS process proven by the results of the document analysis.

\section{a. Learning process}

The researcher divides this learning process into several parts and develop again into several points. The first part is the preparation of the teacher before teaching. The second is the preliminary activity. The third is the core activity. The fourth is the closing activity. 
The first part, the teacher must prepare the lessons before teaching. The teacher plans ways for student to be active and participatory in the learning process. The teacher provides the learning guidelines following the materials that will be studied. The teacher must prepare the learning framework in the form of daily, weekly, monthly, and even annual notes, and also formulating the emphasis on the development of competencies, and developing student behavior habits.

The researcher showed that in the process of teaching English, the teacher could not plan how to made students active in class because of the Covid-19 pandemic, this situation made students learned from home using the online learning process. In this case, the teacher had been prepared the material and strategy for the learning process accordance with online learning. The teacher also prepared a learning framework in the form of weekly notes based on the material that will be taught, and also formulated the emphasis of competencies that are developed, and the teacher developed of student behavior habits.

The first point arranges a scenario about the implementation of inquiries in the learning process, by preparing the material are needed in the discussion. The researcher found that according to the lesson plan for 5 meetings the teacher just prepared the subject matter such as (talking about self, congratulating and compliment, expressing intention and descriptive text) and students were asked to understand the learning material without any feedback from the teacher. The students were asked to answer the questions that the teacher gave. The process of improvement design of thinking in speaking and writing was not provided. So the teacher only prepared learning materials according to the subject matter in the lesson plan.

The second point, the teacher must prepare a classroom environment with the tools, materials, and resources need for the learning process. For this point, the researcher found that, the teacher provided material for students via WAG and google classroom, in the 5th meeting, the teacher used voice notes to explained the learning materials.

The third point there are some technique in teaching speaking and writing to improve (productive skills) based on critical thinking process. The researcher found that, the teacher did not apply the technique well, there was not speaking process that the teacher did, and also for the writing process, students only asked to answer the questions given by the teacher. Students only answered these questions as much as students could, and the teacher did not reread what the student wrote after the students finished the exercises. 
The second part is the preliminary activities. There are several components in the preliminary activities such as, there are some learning framework and also formulates of competencies that are developed. The development of behavior habits and patterns of students thinking. Creating a class atmosphere for comfortable and enjoyable for thinking activities. Preparing materials to stimulate the thinking of students to initiate learning. Bring the students to the reality that exists in society. In this section, the researcher found that the teacher did not ensure that learning focused on the goals that have been made. The teachers did not master the techniques and planed some ways to encouraged students to participated and have a responsibility in learning. This happened because the learning process was carried out by the online process. So, this caused the learning to be ineffective.

The third part is the core activities. These activities starting with level 1 (Provide a brief explanation of the concepts or stimulation lessons). Provide inferential questions to improve students' thinking skills. Encourage students to reveal the knowledge that has been mastered. Creating a comfortable and pleasant classroom atmosphere for thinking activities. In this stage, the researcher found that, the teacher did not provide a brief explanation (stimulation) of the concept in learning process. The teacher asked students to read the material using WAG and google classroom. The teacher did not stimulate the students to give questions to encourage students to think critically, this happened because there were not students asked about the material provided in the WAG. The teacher ignored students to did not gave a question in groups and made students very passive, even though learning was only through WAG, in fact, the students still could to givesome questions by sending voices notes, and the teacher could explain the questions that appeared by sending voice notes, but it was not done, this caused students just accepted what the teacher gave without knowing the students understand it or not.

The fourth point, each learning unit began with a problem-solving formula. The teacher provide the feedback to the student and encouraged students to think, the teacher reveals the knowledge that has been mastered, this section was not carried out by the teacher. The teacher did not ask questions to students.

Level 2: bridge (digging up initial knowledge to link it into the context of new knowledge), in level 2 there are several components such as, the teacher encourages the emergence of responses and when the responses are wrong, the teacher takes students to explore effectively to find why there are misconceptions and find the correct concept. Thus, students will 
have a way to do something that is more correct, at this stage the researcher found that the process did not occur, because the teacher only provided material and allowed students to understand it alone for what the students got, and for the speaking and writing processes, there was not a process of linking knowledge.

The fifth point there is a provides opportunities for students to find problems independently, provides opportunities for students to formulate the problem. Encourages students to find information and data relevant to the problems. in this section, the researcher found that the students were indeed able to solved their own problems without help from the teacher. This happened because the conditions of online learning forced students to understand the learning better without helped from the teacher.

The third point, there are level 3: high-level thinking provides opportunities for students to analyze information and data that already have. Encourages students to develop alternative solutions to the problems. Provides opportunities for students to formulate solutions. In this section, the researcher found that the teacher did not develop higher-order thinking processes for speaking and writing, because the process that has been known was not carried out, this happened because the teacher only provided learning material without develop student potential because of online learning.

The fourth part is the data on the closing activity and evaluation. In the closing activity, there are an assessment of student development and providing facilities in learning. Provide feedback on the learning process and results, carry out follow-up activities in the form of giving assignments in individual and group assignments. Informing the plans of the learning activities for the next meeting. The data that the researcher found that there was no feedback process found between teachers and students to improve students' understanding, there was no assessment process, the teacher only provided exercises to do at home.

The part of the teacher applying HOTS in learning speaking and writing, the researcher found that the teacher did not improve speaking in accordance with the lesson plan that had been made. For 5 meetings, the researcher did not find the speaking process, in the assignments through WAG and google classroom also did not find speaking process, for learning writing the teacher only gave the task of answering questions from the material that has been sent. There was not writing process taught by the teacher, did not find the resume requested by the teacher to 
students according to the lesson plan that has been made, So, the teacher did not apply HOTS in teaching speaking and writing.

Thus, it can be concluded that in the learning process there was not find writing and speaking skill process. The teacher only provided material in the WAG and Google classroom. The forms of material that found used power points, English textbooks and student worksheets scanned into photos, and then distributed through WAG and google classroom.

\section{The implementation of HOTS in teaching receptive skill}

\section{a. Lesson plan}

This section describes the results of what the researcher finds to see how the application of teaching receptive skills according to HOTS criteria. For lesson plan, in course identities, preliminary activities, closing activities, and assessment, the researcher do not describe again because the lesson plan is one unit. The differences are in the core activities that discuss the process of English skills are developed.

For listening process, the teacher provided material about the expressions that are being studied before, for the material found in 4 meetings for 3 subject matter (Talking about self, congratulating and compliment, expression intention) in the lesson planning, there was not audio provided by the teacher during the learning process. The teacher only explained the expression using the teacher's voice. Then students were asked to analyze how the teacher pronounces and understands the form of expression that is given.

For the reading process, the teacher gave reading references for 5 meetings in 4 subject matters. The students were asked to analyze and understand the material that gave by the teacher in the form of reading. The student answers the questions in form of the task provided by the teacher.

Thus, in the lesson plan, there was a process of improving thinking for listening and reading activities. In the listening process, the teacher did not provide an audio reference but the teacher gave the teacher voice to explained the expression, and for reading activities contained in the lesson plan, which showed that students were expected to be able to understand the reading reference that has been given, and understand what the student read according to the subject matter were being taught.

\section{b. Learning process}


The learning process to see how HOTS implement in teaching receptive skills is the same as the process stages in productive skills, because the learning process is also one unit. A good learning process begin with an introduction then core activities then closing activities, to teach HOTS in core activities there is a process of stages from low-order thinking to the high-level thinking process. There are several points that the researcher does not explain again at the part of the learning process because the process can be said in the same way. So, in the learning process to see whether the HOTS process is implemented in receptive skills, the researcher will explain what the researchers find below.

The first part of the core activities, the researcher found the differences in teaching techniques in teaching the receptive skill, in this part showed that the teacher did not apply techniques in teaching listening because the listening process was not done at all from the first meeting into the fifth meeting.

The teacher just applied the techniques in teaching reading because students were asked to understand the material from the first meeting to the fifth meeting. This made students try to understand what they are reading, at the fifth meeting the teacher just gave reading texts to students, and students were asked to analyze the text, in the process of the reading section, the researcher founds that the teacher did a process of thinking levels because students are allowed to develop their thinking skills in reading skill process.

The second point, in the core activities starting with level 1 (Providing a brief explanation of the concept of stimulation lessons). At this stage the researcher found that the teacher gave a brief explanation of the concept of learning (stimulation), the teacher asked students to read the material provided through WAG and google classroom. This happened because the subject matter about the descriptive text which focused on improving reading skills, but the teacher did not ask questions that encouraged students to think critically. This happened because there were not students who asked about the material given in the WAG. The teacher allowed students to did not ask in groups and made students very passive, this caused students just to accept what the teacher gave without knowing whether the students understand it or not.

Third point, Level 2: bridge (done by digging up initial knowledge to link it into the context of new knowledge), it means, the teacher encourages responses and when the responses are wrong, the teacher invites students to explore effectively to find why there are misunderstandings and find the correct concept. Thus, students will have a way to do something 
more correct. At this stage, the researcher found that the process did not occur because the teacher only provided the material and allowed students to understand for themselves what the students got, and for the listening and reading process, there was not knowledge linking process.

The fourth point, Level 3: higher-order thinking, the teacher must give students the opportunity to analyze the information and data they already have. Encourages students to develop alternative solutions in problems. Provides opportunities for students to formulate solutions, in this section researcher found that the teacher did not develop processes high-level thinking in listening skills. The teacher developed high-level thinking skills in reading process. So, students tried to solve their problems, understood the reading that was given and analyzed the reading text.

The part of the activity for the listening process was not carried out at all. The teacher did not prepare the audio and even used the teacher's voice, during 5 meetings the researcher found the teacher only focused on the subject matter, for reading activities, the teacher provided reading references for the subject matter, after that the teacher provided the text for analyzed by students and the teacher instructed students to answer the questions. So, the reading process has increased in the thinking process.

Thus, it can be concluded that, the data contained in the core activity also explained there was not bridge from a lower level of thinking to a higher level of thinking, students were only forced to thought at a higher level by the teacher. The teacher told students to understand each material, without any explanation from the teacher, then the teacher immediately gave assignments according to the material provides. The teacher actually could encourage students to start from low-level thinking by using WAG as best as possible, and also using google meet, so teacher and students could meet face to face, but the fact that the teacher only used WAG and google classroom to support learning. This applied both productive and receptive skills, this made students confused, and this made the learning process not conducive.

\section{B. DISCUSSION}

Based on the description of how teachers' understanding the lesson plans following HOTS criteria, the researcher found that the teacher understood of the lesson plans even though some parts could not find in the lesson plan, for example about how productive skills and receptive skills techniques were developed. The teacher did not describe the material to be used. Besides, the teacher made the lesson plans according to HOTS criteria. 
Based on a description of how the teacher implements HOTS in the English learning process, the researcher found that teachers did not develop HOTS properly. According to Goodson and Rohani (1997) state that applying HOTS-based learning there must be activities that stimulate students to develop the ability to analyze, evaluate and create, this will be achieved if learning takes place in active learning where students are the center. The teacher did not stimulate students to be able to solve their problems. there was not feedback process occurs between teachers and students, only teachers who active in learning, and it can be concluded that learning was still focused on the teacher.

Based on a description of how the teachers increase productive and receptive skills according to the HOTS criteria, the researcher found that there was not increase at all in students' productive and receptive skills, because the teacher did not develop these two skills. First, in the teacher's writing activity did not teach how to develop ideas properly. The teacher only provided practice to answer the questions that have been given. So, it caused students to only analyze but not writing it.

Zohar, A (1999) stated that the failure in teaching productive skills occurs due to the lack of motivation to students given by the teacher, which is often found in every learning process. In speaking activities reasearcher found that the teacher also did not do speaking activities to students, this happened not because of limitations in the online learning process but the teacher did not do anything for this, students were only given dialogue without doing anything. Third, listening activities, the researcher did not find listening activities during 5 meetings but reading activities did happen quite well. Fourth, the teacher gave a reading text then the students were asked to analyze the reading text, then for the reading process the teacher gave the material and the students answered the questions, so productive skill activities and receptive skills are not taught well at all.

According to Rosli and Maarof (2018) emphasize that HOTS acts as a guide for the students to develop their ideas on what they want to write, with HOTS the students are also trained to improve their speaking ability by explaining their ideas and attempting to state what is on their mind to their friends. According to Setyarini and Ling (2019) find that the students who have critical thinking skills are willing to deliver their ideas freely in front of the class without worrying their friends' judgment or mistake. So, those advantages will be owned by the students 
when the students to integrate their higher-order thinking skills with English productive skills and receptive skills.

Weay, A. \& Abdullah, H. (2016) The implementation of HOTS in teaching productive skills and receptive skills can help students' understanding, but the facts were found that there was not process of improvement until the assessment occurs. Teachers only focused on the material. Here, researchers could emphasize that this happened not because of the online learning process, but the teacher did not provide or teach according to the 4 skills needed, there was not speaking process, there was not writing process that made students knew what the students wrote, there was not reading process even though the teacher has given readings to students, there was not listening process given by the teacher. So, at this stage, the process did not happen at all.

Thus, it can be concluded that the implementation of HOTS by the English teacher was not going well, because the teacher did not teach students directly, it happened because of the Covid-19 pandemic which made it difficult for students to be active in learning, it was not an excuse for the teachers to did not prepare strategies to support a conducive learning process during a pandemic. The teacher only provided material, then students were asked to understand the material, and then the teacher gave exercises to the student. The learning process only took place about 20 minutes, only through WAG and google classroom. So, it was very far from the process of ideal learning.

\section{CONCLUSIONS}

Based on the finding and discussion that have been presented in the previous chapter, the researcher concluded that this research focused on the Implementation of HOTS in teaching English. The results obtained that the teacher did not use HOTS in the learning process, the teacher only understands the HOTS criteria only in the lesson plan, the teacher implemented HOTS well in the lesson plan, while in the learning process itself, the teacher did not apply the HOTS process properly. For the productive and receptive skills, there was not level of thinking were found during the learning process, it could be said that for the productive skills process, the teacher did not apply HOTS at all in learning, and for receptive skills teachers also did not apply HOTS well in the learning process. The learning process was still focused on students, there was not improvement has occurred, this happened because the skill was not taught at all. 
The suggestion is mostly addressed to the English teacher at the tenth grade of PONPES MTI Pasia. The teacher should teach learning according to the lesson plan that has been made even though it is difficult to apply. The teacher must teach students the right things and this will add knowledge to students, and the teacher must be able to improve students' abilities in 4 skills (speaking, writing, reading, listening) in addition to the material that has been determined.

\section{REFERENCES}

King, FJ, Ludwika Goodson, and Faranak Rohani. (1997). Higher Order Thinking Skills; Definition, Teaching Strategies, Assessment. Retrieved from: https://scholar.google.com/citations? user $=c x 2 p u \_I A A A A J \& h l=e n .1$-30

Margana, \& Widyantoro, A.( 2017). Developing English textbooks oriented to higherorder thinking skills for students of Vocational High Schools in Yogyakarta. Journal of Language Teaching and Research. 2(1) 20-26 Margono. (2007). Metode Penelitian pendidikan. (2 $\left.{ }^{\text {nd }}\right)$ Rhineka Chipta. 56-67

Rosli, M. F., \& Maarof, N. (2018). The effect of higher-order thinking skills (HOTS) questions in improving ESL pupils' writing performance. Retrieved from Academia Education. 34 Sugiyono. (2010). Methodologi Penelitian Kualitatif and R\&D. Aksara medika beta. 4(1), 34-37

Weay, A. L., Masood, M., \& Abdullah, S. H. (2016). Systematic review of revised Bloom Taxonomy, SOLO Taxonomy and Webb's Depth of Knowledge (DOK) in assessing students' historical understanding in learning history. Malaysian Journal Of Higher Order Thinking Skills In Education. https://www.researchgate.net/publication/309291261_Malaysia_Journal_of_Higher_Or der_Thinking_Skills_in_Education_MJHOTSPromoting_Higher_Order_Thinking_Skills_in_Science_Education, 25-30

Zohar, A. (1999). Teachers' metacognitive knowledge and instruction of higher order thinking. Teaching and Teachers' Education, 15, 413-429. 